EESTI NSV TEADUSTE AKADEEMIA TOIMETISED 1953. II k., nr. 3

ИЗВЕСТИЯ АКАДЕМИИ НАУК ЭСТОНСКОИ ССР 1953. ТоМ II, N 3

\title{
MAJANDUSLIKUD SIDEMED VENEMAAGA BALTIMAADE LINNADE ARENGUTEGURINA KAPITALISMI AJASTUL
}

\author{
V. K. JATSUNSKI, \\ ajalooteaduste doktor
}

Majandusseadus, mille järgi tootmissuhted peavad tingimata vastama tootlike jōudude iseloomule, avaldub linna majanduslikus arengus eriti ilmekalt. Linnas kasvavad tootlikud jõud kiiremini kui maal. Tootlike jõudude kasv linnas avaldub eelkõige linna tööstuse arengus. See tööstuse kasv pole mitte üksnes tema kvantitatiivne laienemine, mille juures toodetakse üha mitmesugusemat toodangut, vaid see on samaaegselt ka tööstuse erakordselt tähtis organisatsioonilis-tehniline ümberkujunemine, mille käigus tööstus läbib kolm staadiumi, mida Lenin kindlaks tegi vene tööstuse kapitalistlikus arengus: väikekaubatootmine - manufaktuur - vabrik. Tööstuse areng toob endaga kaasa tööstusproletariaadi kaadri moodustumise ja juba puht-kapitalistlike tootmissuhete kujunemise. V. I. Lenin näitas, kuidas üha rohkem hääbuvad need patriarhaalsete suhete jäänused ettevôtjate ja tööliste vahel, mis on tootmise manufaktuuri-staadiumis veel säilinud, aga vabriku domineerimise ajaks hoopis kaovad. Arenevad teravad vastuolud töö ja kapitali vahel, tekib töölisliikumine. See on tinna osatähtsuse äärmiselt oluline, pôhimôtteline moment kapitalismi ajastul.

Teiseks momendiks on see, et linn on ühtlasi ka kohaks, kuhu keskendub kaubandus. Kapitalismieelsel ajastul teenindab linn tavaliselt kohalikku, vōrdlemisi vāikest piirkonda, olgugi et see piirkond kasvab juba kapitalismieelsel ajal tunduvalt. Kapitalismi ajastul on linnade kaubanduslik osatähtsus mitmesugune, kuid paljud linnad teenindavad kaubanduslikus suhtes mitte ainult oma piirkonna pöllumajandust, vaid evivad erakordselt kaugeid sidemeid ka muude paikkondadega mitte ainult Venemaal tervikuna, vaid - kui juttu on sadamalinnadest - , ka teiste maadega.

V. I. Lenin, kōneldes tööstuse uurimisest oma töös „Kapitalismi areng Venemaal", rōhutas, et tööstuse paiknemisest täpse ettekujutuse saamiseks tuleb vaadelda tööstust mitte kubermangude ja maakondade kaupa, vaid tööstuskeskuste järgi. V. I. Lenin tegi kindlaks kolm säärast keskuste tüüpi vene kapitalismi ajaloos. Ta klassifitseeris nad peamiselt keskkubermangude materjalide pöhjal, kuid see klassifikatsioon on kohaldatav ka Baltimaade suhtes. Lenin tegi kindlaks, et on olemas vabrikutööstuse

1 Ettekanne Baltimaade rahvaste ajaloo küsimustele pühendatud teisel ühisel teaduslikul sessioonil Vilniuses, 1953. a. märtsis (lühendatud). Olevaade sessioonist vt. ..ENSV TA Toimetised", 1953, nr. 1. 
keskuste kolm peatüüpi: 1) linnad, 2) vabrikukülad ning 3) „kodutöönduslikud" külad ?2.

Kui vaatleme Baltimaid, siis näeme, et eriti selgelt paistis Lätis ja Eestis silma esimene tüüp - linnad. Vabriku-tööstuskülasid, nagu Orehhovo ja Teikovo, oli vähe. Mõningaid asulaid, näit. Sindit, võib nendega kōrvutada, kuid sedagi vaid mōningate reservatsioonidega. Vähe oli ka kodutöönduslikke keskusi.

Seega evib Baltimaade ajaloos tööstuskeskusena linn erilist tähtsust Läti ja Eesti osas. Leedu osas on mõningane tähtsus ka alevikul, olgugi ainult väikekaubanduse ja väiketööstuse alal.

Kõige olulisem ja põhiline on see, et linnal oli Baltimaade oludes suurem majanduslik tähtsus kui linnal Venemaa oludes läbistikku.

Baltimaade linnadel on pikk ajalugu. Iga tänav ja paljud majad Vilniuses könelevad kaugest minevikust. Riia pühitses hiljuti 750 aasta juubelit, kusjuures see tähtpäev pole väga täpne: tema aluseks ei ole Riia asutamine, vaid ainult esimene Riia mainimine kirjalikes allikais. Tallinnat mainitakse esmakordselt ajaloo allikates 1154. aastal. Nende linnade pika ajaloo vältel on järk-järgult kujunenud baas nende hilisemaks majanduslikuks arenguks kapitalismi ajastul.

Kapitalismi ajastul olid Baltimaade linnad ülevenemaalise rahvamajandusliku organismi osaks ja see omakorda mōjustas mitmeti nende majanduslikku arengut.

Baltimaadel võib käesoleva sajandi algusest pärinevate materjalide alusel kindlaks teha linnade kolm pōhitüüpi. Esimene tüüp on puht-tööstuslik linn, mida Baltimaadel on ainult üks - Narva, kus kaubandusel on üsna tagasihoidlik koht. Teise tüüpi kuuluvad keskused, mida võib nimetada peamiselt kaubanduslikeks, sest nendes on vähe tööstusettevõtteid ja needki on väikesed. Selle rühma eesotsas seisab Vilnius suure kaubanduskäibega ja vähese tööstusega, kusjuures seegi on valdavas osas väiketööstus. Sama tüüpi on ka Daugavpils, Tartu, Pärnu ja Siauliai. Kolmanda tüübi moodustavad säärased keskused, kus niihästi tööstus kui ka kaubandus on tugevasti arenenud, nagu Riia, Liepaja ja Tallinn. Samasse rühma kuuluvad ka Kaunas ja Jelgava, olgugi et tööstus on nendes tunduvalt nôrgemini arenenud kui kaubandus.

Nende rühmade järgi asutaksegi allpool teostama analüüsi, kusjuures alustatakse kōige tugevama rühmaga - kaubandus-tööstuslike keskuste rühmaga.

\section{1.}

Alustame Baltimaade linnade analüüsi suurima keskusega - Riia linnaga, mille kaubanduskäive oli vaid veidi väiksem Baltimaade kôigi teiste linnade kaubanduskäibest kokku.

Riia linn XIX sajandi esimesel poolel oli tähtis keskus, mis kaubandus. likus suhtes teenindas suurt piirkonda: Baltimaid, Valgevenet ja nendega külgnevaid vene kubermange, näit. Orjoli kubermangu, samuti ka osa Pōhja-Ukrainast. See territoorium pole väljeveo ja sisseveo osas ühesugune: väljaveo osas on ta suurem, sisseveo osas väiksem.

Juba reformieelsel ajal arenes Riias suurtööstus, ehkki tööliste arvu poolest (umbes 5000 töölist) ei olnud see 50 -ndatel aastatel just väga suur.

Mis puutub tööstusharudesse, siis tuleb kõigepealt mainida metsatööstust. Daugava jõge mööda parvetati metsa ekspordiks, Riias toimus saagimine.

2 V. I. Lenin, Teosed, 3. kd., Ik, 435-436. 
Juba 40-ndatel aastatel tekib selline omapärane tööstus, nagu seda on korkide valmistamine. Korgil oli igapäevases elus, sealhulgas ka mõisamajanduses teatav tähtsus. Korke tuli aga valmistada imporditavast materjalist. Seepärast oli korkide sobivaks valmistamiskohaks sadam. Nõnda rajati 1845. aastal Riias esimene korgitööstus.

Viiekümnendatel aastatel oli Riias olemas ka tubakatööstus. Parunid armastasid suitsetada sigareid, vene valitsuse poolt oli aga sigaritele pandud suurem sisseveotoll kui tubakale. Seepärast tekkiski tubakatööstus, mis algul kasutas tooraineks importtubakat, hiljem aga hakkas kasutama kodumaist tubakat.

XIX sajandi esimesel poolel kasutati Venemaal importsuhkrut, kuid rafinaadi sissevedu oli keelatud. Sisse veeti toorsuhkrut, millest sadamalinnades tehti rafinaadi. Peamiseks linnaks, kus valmistati rafinaadi, oli Peterburi, teiseks Riia ja kolmandaks Arhangelsk. Nōnda arenes Riias suhkrutööstus. Hiljem, reformijärgsel ajastul, kui hakkas arenema Venemaal kasvatatud suhkrupeeti töötlev suhkrutööstus, suleti need tehased.

Riias arenes ka tekstiilitööstus, mis kasutas kohalikku villa ja lina ning välismaalt imporditud puuvilla.

Juba enne 1861. a. reformi olid Riias olemas masinaehitustööstuse alged. Ettevõtjal Wöhrmannil tuli remontida oma Sindis oleva vabriku sisseseadeid ja parandada Riiga sissesōitvaid aurikuid ning ta ehitas 1830 -ndatel aastatel väikese masinaehitustehase. Hiljem asutati Riias veel teisi tehaseid masinaehitustööstuse alal.

Kuid vaadeldes tööliste arvu tööstusharude järgi sel ajal, nảeme, et kôige rohkem töölisi on tekstiilitööstuses ja kôige vähem masinaehitustööstuses.

Töölisteks olid peamiselt lätlased, kuid oli ka vene töölisi. Peremeesteks olid mitte üksnes balti sakslased, vaid ka venelased, näit. Kuznetsov, kes 1843. aastal avas Riias portselanivabriku.

Mis puutub turgu, siis olid peamisteks kaubatarvitajateks Baltimaad. Oksikuid Riia tööstuse tooteid osteti aga ka sise-Venemaal. Riias valmistatud kammvillaste ja villaste kangaskaupadega, mis olid üldiselt tuntud, varustati kôiki Venemaa tolleaegseid tütarlaste ôppeasutusi. Seega oli vene turg mõningate kaupade osas juba tol ajal tähtis Riia tööstuse jaoks.

Pärast 1864. a. reformi arenes Venemaa raudteevõrk tunduvalt, millel oli kapitalismi arengus määratusuur osatähtsus. Just raudtee lülitas Riia ülevenemaalisse turgu. Juba 1861. a. ehitati raudteeliin Riiast Daugavpilsi. Hiljem ühendati raudteeliin Valgevene kaudu ka keskkubermangudega ja 10 aasta pärast ulatus liin juba Tsaritsōnini.

1873. aastal avati raudteeliin, mis ühendas Riiat Jelgava kaudu LiepajaRomnō raudteeliiniga. See andis Riiale ühenduse Ukrainaga ja Kesk-Valgevenega.

1889. aastal valmis Riia-Valga-Pskovi raudtee, mida hiljem pikendati Bologojeni. Sellega loodi ühendus Venemaa loodeosaga. Liiklemine Moskva-Ventspilsi raudteel avati 1901. aastal. Osa sellest raudteest ehitati juba varem.

Raudteeliinide ehitamise tõttu kasvas eksport Riia kaudu tohutult. XX sajandil oli Riial ekspordi osas esikoht Venemaal. Riia kaudu toimus eksport sügavalt Venemaalt. Seega muutus Riia väga tähtsaks sadamaks, mis teenindas mitte ainult Baltimaid, vaid ka küllaltki suurt osa Venemaast.

Riia tööstuslik areng toimus pärast uute ühendusteede loomist kiirendatud tempos ja need suurtööstuse alged, millest eespool oli juttu, hakkasid tormiliselt kasvama. 
1864. aastast kuni 1914. aastani kasvas tööliste arv Riias 13-kordseks. Samal ajavahemikul kasvas tööliste arv kogu Venemaal $4 \frac{1}{3} \mathrm{korda}$. V. I. Lenini arvestuste kohaselt oli Riia 1879. aastal tööliste arvu poolest kolmandal kohal Venemaal (Poola kaasa arvamata), jäädes maha vaid Peterburist ja Moskvast. Tööliste arvu kiire kasv Riias polnud ühtlane. Riia tööstusel oli kolm kasvuperioodi: esiteks 1860-ndate aastate teine pool ja 1870-ndad aastad, teiseks 1890-ndad aastad ja kolmandaks aastad enne esimest maailmasõda. Seega kasvas Riia koos ülevenemaalise majandus. liku arenguga, tehes kaasa selle tõusud ja seisakud.

Kui vaadelda üksikuid tööstusharusid, siis arenes 60 -ndatel ja 70 -ndatel aastatel eriti masinaehitus ja vagunite tootmine. Viimane oli tihedalt seotud raudteede ehitamisega. Alguses asutas üks välismaine firma Riias kokkumonteerimistehase, hiljem kujunes sellest Vene-Balti tehas. Arenes ka tööstuslike seadmete tootmine kohalikele ettevôtetele - nahatööstusele, viina- ja ôlletehastele, veskitele ja saeveskitele. Hiljem aga hakati vastavaid seadmeid tootma kogu Venemaa jaoks. Arenes traaditootmine ja traadist esemete valmistamine, milleks kasutati välismaalt sisseveetavat metalli. See oli ajajärk, millal metalli lubati importida tollivabalt või väga madala tolliga.

Teisel tôusuperioodil - 1890-ndatel aastatel — kasvas jällegi kiiresti masinaehitus, kusjuures väga tähtsat osa etendas väliskapital. Asutati teine vagunitehas. Saksa firma Klein rajas tehase, mis varustas sisseseadetega Uraali ja Ukraina mustametallurgia ettevōtteid ja rida teisi tehaseid. 90-ndate aastate lōpus tekkis elektrotehnika tööstus, mille haaras saksa kapital enda kätte. Nagu hiljem selgus, oli ettevõtte omanikuks tuntud trust - Allgemeine Elektrizitäts-Gesellschaft (AEG). Sisseveetava toormaterjali ja ulatusliku Venemaa siseturu baasil arenes Riias kiiresti ka kummitööstus.

Enne esimest maailmasõda elas Riia tööstus üle järjekordse tõusu.

Riia tööstus oli keskendunud suurteks ettevōteteks. Tööstuse kontsentratsioon üha kasvas. Uldiselt sarnanes Riia tööstus oma tüübilt Peterburi tööstusele, mis pole juhuslikuks nähtuseks, sest olid ju Peterburis samad ajaloolised tingimused. Riia töölisklass moodustus lätlastest ja venelastest ning kapitalismi perioodi lõpus oli märkimisväärne osa ka leedulasi. Linna majanduslikku arengut peegeldab elanikkonna kasv 77000 -lt 1863. aastal rohkem kui poole miljonini 1914 , aastal.

Mõne sõnaga on vaja peatuda ka $\mathrm{L}$ i e p a j a juures. Liepaja sadam on Riia omast parem. Kuid kuni raudteede ehitamiseni oli Liepaja majanduslik tähtsus väike. Pärast seda, kui valmis Liepaja-Romnõ raudtee, hakkas linn arenema sama tüüpi linnaks nagu Riia, jäädes oma suuruselt viimasest aga tunduvalt maha.

T a II in n oli kapitalistliku korra kujunemise perioodil kubermangulinn ja sõjasadam. Ta oli keskuseks ka Eestimaa kubermangu aadlile. Kuid majanduslikus suhtes arenes linn nōrgalt. Tööstuse kapitalistlik areng, mis Eestis sel ajal ilmnes juba küllalt selgelt, toimus väljaspool Tallinna, eelkōige Narvas, samuti ka Sindis ja Kärdlas. Tallinn oli kaubasadam, kuid tema väliskaubandus polnud suur. Seda näitab tabel 1 .

Need arvud näitavad, et vastupidiselt Riiale oli Tallinn sisseveosadamaks ja et tema väliskaubanduslik käive oli reformieelsel perioodil väike. Ainult viimase viie aasta jooksul enne pärisorjuse kaotamist Venemaal hakkas Tallinna kaubakäive vähehaaval kasvama. 
Sisemaalt saabuvate veeteede puudumine ja Tallinna geograafiline asend üldse oli põhjuseks sellele, et Tallinna sadama tähtsus impordi osas piirdus peamiselt Eestimaa ja Pskovi kubermangudega, milledele ekspordi osas lisandus veel külgnev tükk Liivimaa kubermangu.

Tabel 1

Tallinna sadama keskmine aastane kaubakäive ${ }^{3}$

\begin{tabular}{c|c|c|c|c}
\hline \multirow{2}{*}{ Aastad } & \multicolumn{2}{|c|}{ Va 1ja vedu } & \multicolumn{2}{c}{ Sis s ve d u } \\
\cline { 2 - 3 } \cline { 5 - 5 } & $\begin{array}{c}\text { tuhandetes } \\
\text { rublades }\end{array}$ & $\begin{array}{c}\text { protsentides } \\
\text { Riia ekspordist }\end{array}$ & $\begin{array}{c}\text { tuhandetes } \\
\text { rublades }\end{array}$ & $\begin{array}{c}\text { protsentides } \\
\text { Riia impordist }\end{array}$ \\
\hline & & & 523 & 12,4 \\
$1841-1845$ & 248 & 1,9 & 416 & 9,2 \\
$1846-1850$ & 369 & 2,7 & 543 & 16,1 \\
$1851-1855$ & 375 & 4,1 & 931 & 19,1 \\
$1856-1860$ & 648 & 3,2 &
\end{tabular}

Sisseveo ülekaal väljaveo üle seletub peamiselt kahe asjaoluga. Esiteks asetses Tallinnast suhteliselt mitte kaugel teine, samuti kohaliku tähtsusega sadam - Pärnu, mis tõmbas ära eksportveosed, ja teiseks oli Tallinn imporditavate kaupade jaotamise keskuseks. Tallinna kaudu eksporteeriti lina, kanepit, vilja, viina ja villa.

Nii väljaveo ulatuselt kui ka üldise kaubakäibe poolest jäi Tallinn reformieelsetel aastatel tunduvalt maha Pärnust, mis aga oli ainult ekspordisadamaks. Viiekümnendate aastate paiku oli Tallinnal juba veidi suurem käive kui Pärnul. Olles küll peamiselt kohalikuks sadamaks, omas Tallinn siiski juba tol ajal teatud tähtsust Venemaa väliskaubandusele üldse. Tallinna sadam külmus hiljem kinni ja vabanes jääst varem kui Peterburi sadam. Seepärast oli Tallinn varakevadel ja hilissügisel teatavaks abisadamaks kaupade sisseveol Peterburisse. Need kaubad viidi Tallinnast Peterburi maad mööda ${ }^{4}$.

Kuuekümnendatel aastatel avaldas Tallinna väliskaubandus kõikumisi üksikute aastate kaupa, kuid keskmiselt jäi tema käive umbes samale tasemele, nagu see oli 50-te aastate teisel poolel (tabel 2).

Tabel 2

Tallinna sadama keskmine aastane kaubakäive tuhandetes rublades ${ }^{5}$

\begin{tabular}{c|c|c|c}
\hline Aastad & Valjavedu & Sissevedu & $\begin{array}{c}\text { Oldine } \\
\text { kaubakaive }\end{array}$ \\
\hline $1861-1865$ & 456 & 978 & 1434 \\
$1866-1869$ & 323 & 992 & 1315
\end{tabular}

Olukord muutus murranguliselt pärast Paldiski-Tallinn-Tosno ${ }^{6}$ raudteeliini avamist, mis ühendas Tallinna Venemaa raudteevörguga. Tallinna

3 Andmed välja- ja sisseveo kohta on vōetud väljaande «Государственная внешняя торговля в разных ее видах» vastavatest aastakäikudest. Viie aasta keskmised ja protsendid vōrdluseks Riia ekspordi ja impordiga on autori poolt arvutatud.

4 Т. П. Небольскин, Статистическне записки о внешней торговле России, ч. I, СПб., 1835.

5' Arvud on vōetud väljaannetest «Государственная внешния торговля в разных ее видах $(1861-1862)$ ја євнды внешней торговли $(1863-1869)$ ». Keskmised on autori poolt arvutatud. 60-ndate aastate teisel poolel on vōetud neli aastat viie asemel, sest 1870. a. sai Tallinn raudteeūhenduse Venemaaga, mis olukorda pōhjalikult muutis.

6 Tosno - raudteejaam Peterburi-Moskva liinil, $53 \mathrm{~km}$ kaugusel Peterburist. 
väliskaubanduslik käive tõusis kohe järsult, kusjuures sissevedu kasvas väljaveost kiiremini (tabel 3 ).

Tabel 3

Tallinna sadama keskmine aastane kaubakäive ?

\begin{tabular}{|c|c|c|c|c|c|}
\hline \multirow[b]{2}{*}{ Aastad } & \multicolumn{2}{|c|}{ Valjavedu } & \multicolumn{3}{|c|}{ Sissevedu } \\
\hline & $\begin{array}{l}\text { milj. } \\
\text { rublades }\end{array}$ & $\begin{array}{c}\% \text { \%vorreldes } \\
\text { Riiaga }\end{array}$ & $\begin{array}{l}\text { milj. } \\
\text { rublades }\end{array}$ & $\begin{array}{l}\% \% \text { võrreldes } \\
\text { valljaveoga }\end{array}$ & $\begin{array}{c}\text { \% \% vōrreldes } \\
\text { Riliaga }\end{array}$ \\
\hline $\begin{array}{l}1866-1870 \\
1871-1875 \\
1876-1880 \\
1881-1885 \\
1886-1890 \\
1891-1895 \\
1896-1900 \\
1901-1905 \\
1906-1910 \\
1911-1913\end{array}$ & $\begin{array}{l}0,5 \\
7,1 \\
20,2 \\
17,0 \\
19,0 \\
14,6 \\
28,2 \\
25,6 \\
17,8 \\
21,7 \\
\end{array}$ & $\begin{array}{r}1,6 \\
18,9 \\
36,7 \\
30,0 \\
35,7 \\
28,5 \\
40,2 \\
23,1 \\
11,3 \\
10,2\end{array}$ & $\begin{array}{l}1,5 \\
36,2 \\
69,8 \\
79,2 \\
50,7 \\
34,3 \\
58,0 \\
55,5 \\
61,7 \\
88,1\end{array}$ & $\begin{array}{l}300 \\
510 \\
346 \\
466 \\
267 \\
235 \\
206 \\
217 \\
347 \\
406\end{array}$ & $\begin{array}{r}10,4 \\
160,9 \\
214,1 \\
289,1 \\
240,3 \\
132,1 \\
109,0 \\
65,2 \\
54,1 \\
55,3\end{array}$ \\
\hline
\end{tabular}

Juba esimese viie aasta jooksul pärast Tallinna ühendamist Venemaa raudteevôrguga kasvab import Tallinna kaudu 24-kordseks. Impordi osas jōudis Tallinn Riiast ette. Järgmise vile aasta jooksul sissevedu Tallinna kaudu kasvas peaaegu kahekordseks ja Tallinn, minnes Odessast ette, jôudis Venemaa sadamate hulgas sisseveo osas teisele kohale, jäädes maha vaid Peterburist. Aastatel $1881-1885$ oli Tallinnal sisseveo osas koguni esikoht Venemaa sadamate hulgas. Kuid juba järgmise viie aasta jooksul, aastatel 1886-1890, sissevedu Tallinna vähenes ja Tallinn loovutas esikoha Peterburile.

Hiljem oli Tallinn sisseveo osas harilikult kolmandal kohal, jäädes peale Peterburi maha kas Odessast või Riiast ${ }^{8}$.

Oma impordiga teenindas Tallinn Peterburi kõrval eelkōige Venemaa kesktööstusrajooni. Ta muutus esimeseks Venemaa sadamaks puuvilla sisseveo alal. Tallinna kaudu veeti sisse palju masinaid kesktööstusrajooni jaoks, samuti keemiasaadusi. Imporditi ka tarbekaupu.

Vastavalt Tallinna tööstuse kasvule, mis hakkas arenema seoses siseVenemaa turuga, kasvas ka kivisöe ja tööstustoorainete sissevedu Tallinna enda vajaduste katteks. Nagu tabelist nähtub, jäi Tallinn kuni esimese maailmasōjani oma loomult sisseveosadamaks, nagu Peterburigi. Kuid ka Tallinna eksport kasvas vägagi tugevasti, koosnedes peamiselt mitte Eestimaa toodetest, vaid kaupadest, mis tulid sise-Venemaalt.

Nagu juba mainitud, oli Tallinn reformieelsel ajastul tööstuse poolest nõrgalt arenenud. Kuuekümnendatel ja seitsmekümnendatel aastatel edenes tema tööstuslik areng vähe. 1879. aastal oli Tallinnas kaubanduse ja manufaktuuri departemangu andmeil tööstusettevōtetes kokku 417 töölist ${ }^{9}$.

Mõned väiksemad ettevōtted (kaks väikest põllumajandusmasinate tehast jt.) kujunesid täielikult kohalike majanduslike tingimuste ja koha-

7 Arvud on vōetud raamatust „Die Entwicklung des Rigaer Handels und Verkehrs im Laufe der letzten 50 Jahre bis zum Ausbruche des Weltkrieges" von Bruno von Gernet, Jena 1919. Tallinn on vōetud koos Paldiskiga, mis oli Tallinna abisadamaks. Protsendid on arvutatud autori poolt.

8 90-ndatel aastatel jāi Tallinn maha Odessast, aastatel 1901-1905 nii Odessast kui ka Riiast. Seega jäi Tallinn neljandale kohale. Pärast jôudis Tallinn Odessast ette ning jäi maha vaid Peterburist ja Riiast.

9 Andmed on vōetud rasmatust П. А. Орлов, Указатель фабрнк и заводов Европейской России, СПб. 1881. See arv ei hőlma raudteetöökodade töölisi, kelle kohta nimetatud raamatus andmed puuduvad. 
liku nõudmise môjul, kuigi nende toodang mōningal määral vôis minna ka väljapoole Baltimaid.

Ilmselt polnud vene turg 70-tel aastatel veel jôudnud Tallinna tööstuse suurusele ja struktuurile mõju avaldada. Kaheksakümnendatel aastatel asutati Tallinnas vähe uusi ettevôtteid ja üldse oli tööstuse areng linnas nendel aastatel aeglane, mis kajastas üldist seisakut nii kogu Venemaa kui ka Baltimaade rahvamajanduses. Ettevõtete hulgast, mis sel ajal tekkisid, tuleks mainida E. J. Johansoni paberivabrikut ja Lutheri puidutööstust, mis hakkas valmistama vineeri ning sellel baasil kasvas hiljem suurettevôtteks. Tallinna vabrikute ja tehaste toodangut hakatakse juba sel ajal saatma märkimisväärses koguses ka vene turule.

1890. aastal oli Tallinna suurtööstuses tööliste üldarv 854 inimest ${ }^{10}$.

Oheksakümnendatel aastatel toimunud tööstuslik tõus kutsus ka Tallinnas esile mitte üksnes olemasolevate ettevôtete laiendamise, vaid ka rea uute vabrikute ja tehaste rajamise. Need uued ettevōtted tekkisid peamiselt 90-ndate aastate lōpul. Nad määrasid pōhijoontes ära tööstuse eriharud, mis olid iseloomulikud Tallinna tööstusele imperialismi ajastul.

Nendeks olid eelkõige masinaehitustehased. Esikohal nende hulgas oli a/s „Dvigateli" vaguniehitustehas, mis asutati 1898. aastal. See tehas, samuti kui "Phönix'i” tehas Riias, pidi rahuldama uute raudteede ehitamisega suurenenud nõudmist veereva koosseisu järele. Tehase toodang oli määratud ülevenemaalise turu jaoks. Aastal 1900 töötas „Dvigateli” tehases 2260 inimest 11 ja ta oli sel ajal Tallinna suurim ettevôte ${ }^{12}$.

Oheksakümnendate aastate lõpul tekib Tallinnas elektrimasinatööstus. 1899. aastal asutati Tallinnas „Volta” elektrimasinate tehas, mis hakkas tootma mitmesuguseid elektrimootoreid. Toodang leidis turgu kogu Venemaal.

Tallinn oli Venemaa peamiseks sadamaks puuvilla sisseveo alal, ent kuni 90-ndate aastate lõpuni ei olnud Tallinnas puuvillatööstust. Kuid üheksakümnendate aastate tööstuslik tôus tôi endaga kaasa selle tööstuse tekkimise ka Tallinnas. 1899. aastal asutati Tallinnas suur puuvillaketramis- ja -kudumisvabrik „Balti Manufaktuur”.

Sel ajal arenes Tallinnas ka keemiatööstus. Samuti rajati küllaltki suur tselluloosivabrik. Suurtööstuse tööliste arv Tallinnas tôusis 1900. aastal umbes 6000 inimesele.

Tallinna tööstus, mille toodang sajandi algul valitsenud kriisi ja sellele järgnenud depressiooni löökide all oli kahanenud, hakkas XX sajandi esimese aastakümne lôpul uuesti kasvama. See kasv toimus eriti kiiresti tööstusliku tõusu perioodil aastatel 1910 - 1913, millal Tallinna rajati kolm suurt laevaehitustehast. Nende tehaste ehitamisega kasvas Tallinn üheks suuremaks laevaehituskeskuseks Venemaal. Köige suuremaks nendest tehastest oli Vene-Balti laevaehitustehas, kus esimese maailmasõja aastatel töötas üle 7000 töölise.

Teistes tööstusharudes toimus mitte niivõrd uute ettevõtete rajamine, kui juba olemasolevate vabrikute ja tehaste laiendamine. Tööliste üldarv suurtööstuses tõusis üle 15000 inimese. Tallinna tööstus kasvas XX sajandil kiiremini kui Riia ja Liepaja tööstus.

Tallinna suurtööstuse struktuur 1914. aastaks tööstusharude järgi on antud tabelis 4 .

10 Andmed on võetud raamatust «Указатель фабрик и заводов Европейской России», под ред, Орлова и Будагова. Изд. З, СПб, 1894

II жСиисок фабрик и заводов Европейской Россинз, СПб., 1903.

$12 \mathrm{XX}$ sajandil tööliste arv kahanes, mis oli tingitud nōudmise vähenemisest vagunitele Venemaal. 
Tallinna suurtööstuse struktuur

\begin{tabular}{|c|c|c|c|}
\hline \multirow{2}{*}{ Tööstusharud } & \multicolumn{3}{|c|}{ Töoliste arv ${ }^{3}$} \\
\hline & 1890. a. & 1900. a. & 1914. a. \\
\hline $\begin{array}{l}\text { Metallitööstus } \\
\text { Puidutööstus } \\
\text { Tekstiilitööstus } \\
\text { Keemiatööstus } \\
\text { Paberi- ja polügraafiatōöstus } \\
\text { Toiduainetetööstus } \\
\text { Nahatööstus } \\
\text { Muud tööstusharud }\end{array}$ & $\begin{array}{r}337 \\
200 \\
34 \\
66 \\
93 \\
124 \\
- \\
-\end{array}$ & $\begin{array}{c}3726 \\
1132 \\
180 \\
217 \\
352 \\
309 \\
33 \\
-\end{array}$ & $\begin{array}{r}8662 \\
2435 \\
1877 \\
450 \\
1202 \\
441 \\
60 \\
257\end{array}$ \\
\hline & 854 & 5949 & 15384 \\
\hline
\end{tabular}

Masinaehitus ja metallitööstus haaras üle poole Tallinna suurtööstuses töötavatest töölistest. 1900. aastal oli esikohal vaguniehitus. XX sajandi esimesel aastakümnel vähenes vaguniehituse alal töötajate arv Venemaa raudteede ehituse vähenemise tagajärjel nii suhteliselt kui ka absoluutselt. „Dvigateli" tehases töötas 1908. ja 1909. aastal alla 800 inimese ${ }^{14}$. Esimesele kohale Tallinna masinaehituses ja metallitööstuses tõusis laevaehitus. Tallinna tehased ehitasid nii kauba- kui sõjalaevu. Tallinnas toodeti samuti aurukatlaid, viinavabrikute sisseseadeid, masinaid puidu töötlemiseks ja külmutusseadmeid. Valmistati üsna märkimisväärsel hulgal plekkesemeid - peamiselt konservikarpe. Elektrotehniline tehas „Volta” laiendas tootmist, kuid see ettevōte oli võrreldes AEG tehastega Riias võrdlemisi tagasihoidlik: 1. jaanuaril 1914. a. moodustas "Volta” osaühingu aktsiakapital 2 miljonit rubla, AEG aktsiakapital aga 12 miljonit rubla ${ }^{15}$. Tallinna masinaehitustööstus töötas peaaegu tervenisti ülevenemaalise turu jaoks.

Puidu töötlemine kasvas peamiselt toodangu suurendamise arvel Lutheri vabrikus, kus 1914. aastal töötas üle 2000 töölise. See vabrik valmistas vineeri ja mööblit, mis läks nii Venemaa turule kui ekspordiks. Teised ettevōtted selles tööstusharus olid peamiselt saeveskid.

Tekstiilitööstus oli esindatud peaaegu ainult Balti Manufaktuuri näol. Ulejäänud selle tööstusharu ettevōtted olid tähtsusefud. Balti Manufaktuuri tööliste arv tõusis 1914. aastaks üle 1800 . Keemiatööstuses oli peamiseks ettevôtteks Mayeri tehas (350 töölist 1914. a.), mis valmistas ülevenemaalise turu jaoks happeid ja värvaineid. Paberitööstuses oli kaks suurt ettevōtet - tselluloosivabrik 700 töölisega ja paberivabrik, kus töötas 220 inimest.

Kōrvutades Tallinna tööstuse tootmisharude struktuuri Riia ja Liepaja tööstuse struktuuriga, ei ole raske näha, et Tallinn kuulub samasse tüüpi. Tööstusharude koosseis ei olnud Tallinnas, samuti nagu Liepajas, nii täielik kui Riias. Tööstustoodangu ulatuse poolest ületas Tallinn Liepaja tundu-

13 Kasutatud statistilised andmed ei haara metallitōōstuse tööliste osas Tallinna raudteetehaseid ega Tallinna sadamatehaseid. 1900, a. kohta toodud andmete kohta tuleks märkida, et Tallinna tööliste arv suurenes tunduvalt 1900-1901. a. Ainuüksi Balti Manufaktuuris tôusis ettevôtte töölerakendamisega tööliste arv uีle 1000 (tabelis tekstiilitōöliste arv 1900. a. on antud 180). Suurenes tööliste arv ka Dvigatelis, Lutheris ja reas teistes ettevōtetes. (Toim.).

14 Р. Д. К анда уров, Фабрнчно-заводские предприятия Р Российской Империи, Петроград, 1914

15 В. С, 3 и в, Иностранные капиталы в русских акционерных предприятиях. Вып, I. Германские капиталы, стр. 32. П. 1915. 
valt. Metallitööstus Liepajas oli esindatud eeskätt metalli valtsimisega ja naelte valmistamisega, masinaehitus oli teisel kohal, elektrotehnika aga puudus üldse.

Vastavalt tööstusharude struktuurile etendas imporditud tooraine Tallinna tööstuse ajaloos palju väiksemat osa kui Liepajas ja Riias.

Tallinna elanikkond XIX sajandi algul oli politsei andmete järgi, mis olid muidugi üsna umbkaudsed, 17000 inimest (1811. a.) ${ }^{16}$. Kuni 1850 -ndate aastate keskpaigani kõikus see arv 20000 ümber ${ }^{17}$. Kaubanduse mõninga elavnemise tagajärjel 1850-ndate aastate teisel poolel tõusis Tallinnas elanikkonna arv 1863. aastaks $28000-$ le $^{18}$. 1860-ndail aastail ei kasvanud ta peaaegu üldse: 1871 , a, rahvaloenduse ${ }^{19}$ andmeil oli elanikkonna üldarv 31300 .

Pärast Tallinna ühendamist Venemaa raudteevốrguga ja seoses tema arenguga kaubanduslikus, seejärel aga ka tööstuslikus suhtes, hakkas elanikkonna arv kasvama. 1881. a. rahvaloenduse ${ }^{20}$ järgi oli Tallinnas 50500,1897 . a. rahvaloenduse ${ }^{21}$ järgi -64600 inimest. Linna aadresslaua andmeil oli 1. jaanuaril 1910. a. Tallinnas juba 91600,1 . jaanuaril 1914. a. -131100 elanikku ${ }^{22}$.

See elanikkonna arvu kasv toimus Tallinnas elanike juurdevoolu arvel. 1897. a. rahvaloenduse järgi oli $64 \%$ linna elanikkonnast sündinud väljaspool Tallinna, samal ajal kui teistes Eestimaa kubermangu linnades moodustas väljaspoolt tulnud elanikkond: Rakveres - 23\%, Paides - $24 \%$, Haapsalus - $14 \%$.

Eespool leidsid käsitlust kolm suuremat sadamakeskust, mis olid seotud kogu Venemaaga niihästi raudteeliinide kui ka kaubanduslike ja tööstuslike suhete poolest.

Kuid Baltimail olid olemas veel sisemaised kohaliku tähtsusega kaubanduslik-tööstuslikud keskused. Nendest olid suurimad Kaunas ja Jelgava. Geograafilises mõttes on Kaunasel parem asukoht. Asetsedes Vilija jōe Neemenisse suubumise kohal, oli ta veetranspordi sõlmpunktiks ja seepärast kasvas ta majandusliku keskusena juba reformieelsel ajajärgul. Suurt osa etendas Kaunases palgiparvetus.

Kaunas lülitati varakult Venemaa raudteevõrku. Ta sai 60 -ndate aastate algul Peterburi-Varssavi magistraalilt raudteeharu, mis läbis Kaunase. Hiljem ehitati raudteeühendused teistes suundades ja Kaunase asend üldises raudteevõrgus kujunes soodsaks.

Kuid Kaunase kaubanduslik-tööstuslikul arenemisel oli raskusi, mis seisnesid selles, et ta hakkas arenema teistest naaberkeskustest hiljem. Riia ei olnud kuigi kaugel, Vilnius - veelgi ligemal. See tegi Kaunasest kohaliku tähtsusega kaubanduskeskuse.

Arenema hakkava suurtööstuse kõrval oli Kaunases olemas ka väiketööstus, mis sarnanes Vilniuse omaga. Tööstuse arenguga kasvas ka elanikkond. Nii kujunes Kaunas kohalikuks kaubanduslik-tööstuslikuks keskuseks, kuigi tema metallitööstuse saadusi saadeti ka ülevenemaalisele

16 К. Г ерм ан, Статистические нсследования относительно Российской империн. спб. 1819.

17 Väga vōimalik, et see on kōikumine mitte niivỗrd elanikkonna arvus, kui just arvutamise täpsuses.

18 Статистический Временник Российской империи, т. І. СПб. 1866.

19 Die Resultate der Volkszählung der Stadt Reval am 16 November 1871. Reval 1874.

${ }_{20}$ Ergebnisse der estlāndischen Volkszählung am 29 Dezember 1881. I Band, Die Zählung in Reval, Reval 1883.

21 Первая всеобщая перепнсь населения Российской империи 1897 r. Окончательно установленное наличное население городов, СПб. 1905 .

${ }_{22}$ Статистическне сведення по городу Ревелю за первую половину 1914 г. Ревель 1914. 
turule. J e lg a va oli tööstuslikus suhtes Kaunasest tugevam, terve rida tema ettevōtteid andis toodangut Venemaa jaoks. Nii muutus Kuramaa saksa aadli vana pealinn tööstuskeskuseks, kuhu koondus hulgaliselt tööstusproletariaati.

Narva arenes puhtakujulise tööstuskeskusena. Tööstuse areng Narvas jättis Narva sadama osatähtsuse kaugele tagaplaanile. Kuid samal ajal oli see sadam Narva tööstusliku arengu üheks eelduseks, kuigi mitte köige tähtsamaks.

Reformieelsel ajajärgul oli Narva sadam väliskaubanduse osas umbes vōrdne teiste Balti mere sadamatega, välja arvatud muidugi Peterburi ja Riia. See olukord ei muutunud ka kuuekümnendail aastail. Alles järgmisel aastakümnel tōstis raudtee-ehitus tunduvalt esile Tallinna ja Liepaja.

Narva tööstusliku arengu otsustav eeldus oli selles, et ühe versta kaugusel ülalpool linna paiknevad kuulsad Narva kosed. Võimalus joa vee-energiat masinate liikumapanekuks ära kasutada oli peamiseks momendiks, mis sundis kapitaliste valima Narva (öigemini tema ümbruse) tööstusettevõtete ehitamise paigaks. Selle eelise väärtus suurenes seoses Narva üldise geograafilise asendiga - lähedal merele ja suhteliselt lähedal Peterburile.

Venemaal feodaal-pärisorjusliku süsteemi raamides toimuva kapitalistlike suhete arengu ajajärgul algaski Narva tööstuslik areng. Esimesed tekstiiliettevōtted olid siin ehitatud juba 20 -ndate aastate algul ${ }^{23}$. 1836. a. müüs kaupmees Momma - kalevimanufaktuuri omanik - manufaktuuri aktsionäride kompaniile ${ }^{24}$, mille rajajaks olid kaupmehed (sealhulgas ka Momma ise) ja silmapaistvad Peterburi võimukandjad — välisminister Nesselrode 25 ja III osakonna ülem Benkendorff. Kompanii asjad läksid halvasti ja 1845. aastal müüdi vabrik ettevōtja Stieglitzile ${ }^{26}$, kellele kuulus suur puuvillaketrusvabrik Peterburis. Stieglitzi kalevivabrikus töötas 1850. aastal 600 töölist. 1851. aastal asutas Stieglitz Narva lähedal linaketramise vabriku. 1860. aastal töötas seal 525 inimest. Mõlemad Stieglitzi vabrikud kasutasid algul vesirattaid, hiljem asendati need veeturbiinidega ${ }^{27}$.

1857. aastal asutas Moskva kapitalist Knoop koos Moskva ettevōtjate vendade Hludovite, Soldatenkovi ja teistega Kreenholmi saarel, mis asetseb Narva jōe kahe kose vahel, suure puuvillavabriku - Kreenholmi Manufaktuuri. Knoop oli kesk-tööstusrajooni puuvillaettevōtete varustajaks puuvilla, inglise kedruse ja masinatega. Sel viisil sai Knoopist paljude puuvillaettevōtete osanik ${ }^{28}$. Valides kohta uue suure puuvillavabriku ehitamiseks, arvas Knoop kõige tulusama olevat rajada see vabrik Kreenholmi saarele, arvestades seejuures kaht asjaolu: koskede vee-energia olemasolu ja Narva lähedust merele, mis võimaldas minimaalsete transpordikuludega saada puuvilla ja masinaid.

23 Л. Лооне, Нз исторни промышленного переворота в Эстонии. Вопросы историн, 1952, № 5 .

24 А. B. Пं етров, Город Нарва. СПб. 1901, стр. 441.

${ }_{25}$ Nesselrode omandas samuti Venemaa puuvillaketruse manufaktuuri aktsiad Peterburis, - vt. autori artiklit Промышленный переворот в России. Вопросы истории, 1952, № 12 .

А. В. Петров, Цнтнр, соч.

А. В. П ет ров, Цитир. соч.

28 Knoopi kohta vaata brošüüri (ilma autori äramärkimiseta) - Контора Кноп и ее значение, СПб, 1895. Brošüüri sisu on refereeritud M. J. Tugan-Baranovski poolt tema raamatus Русская фабрика (ч. II, гл. I). 
Kreenholmi Manufaktuuri ketrusvabrik alustas tööd 1858. a. oktoobris ja kudumisvabrik - 1859. a. augustis. Kreenholmi Manufaktuuri edasine laienemine on näha tabelist 5 .

Tabel 5

Kreenholmi Manufaktuuri sisseseade ja toodang 1858. -1913. a. ${ }^{29}$

\begin{tabular}{|c|c|c|c|c|}
\hline \multirow[b]{2}{*}{ Aastad } & \multicolumn{2}{|c|}{ Tóotavate } & \multicolumn{2}{|c|}{ Toodetud } \\
\hline & $\begin{array}{c}\text { vartnate } \\
\text { arv }\end{array}$ & $\begin{array}{l}\text { kudumis- } \\
\text { telgede arv }\end{array}$ & $\begin{array}{l}\text { kedrust } \\
\text { (puuda) }\end{array}$ & $\begin{array}{l}\text { kangaid } \\
\text { (arssinat) }\end{array}$ \\
\hline $\begin{array}{l}1858 \\
1859 \\
1860 \\
1861 \\
1866 \\
1871 \\
1876 \\
1881 \\
1886 \\
1891 \\
1896 \\
1901 \\
1906 \\
1912 \\
1913\end{array}$ & $\begin{array}{r}10440 \\
34431 \\
58058 \\
64232 \\
104211 \\
177185 \\
252185 \\
289131 \\
340759 \\
389152 \\
419252 \\
453380 \\
460280 \\
472500 \\
509280\end{array}$ & $\begin{array}{r}\overline{516} \\
516 \\
996 \\
960 \\
1578 \\
1821 \\
2177 \\
1004 \\
2136 \\
2138 \\
2500 \\
3024 \\
3672 \\
3767\end{array}$ & $\begin{array}{r}58638 \\
110150 \\
220654 \\
447680 \\
589000 \\
619000 \\
1078289\end{array}$ & $\begin{array}{r}4000345 \\
11000000 \\
23185000 \\
35666000 \\
39750000 \\
44672000 \\
105606707\end{array}$ \\
\hline
\end{tabular}

1914. aastal töötas vabrikus 9900 töölist.

Kreenholmi Manufaktuur kasvas mitte ainult Venemaa, vaid ka kogu Euroopa kōige suuremaks puuvillaketrusettevōtteks (vrd. tabel 6).

Tabel 6

Värtnate ja kudumistelgede arv mōnedes Venemaa suuremates vabrikutes enne esimest maailmasōda

\begin{tabular}{|c|c|c|}
\hline \multirow{2}{*}{ Vabriku nimetus } & \multicolumn{2}{|c|}{ Sisseseade } \\
\hline & vărtnad & kudumisteljed \\
\hline Savva Morozovi Nikolski Manufaktuur & 200966 & 3745 \\
\hline Vikula Morozovi Nikolski Manufaktuur & 177000 & 2500 \\
\hline $\begin{array}{l}\text { Morozovite Bogorodsko Gluhhovski Ma- } \\
\text { nufaktuur }\end{array}$ & 176003 & 3400 \\
\hline $\begin{array}{l}\text { Vendade Hludovite Jegorjevski Manu- } \\
\text { faktuur }\end{array}$ & 202738 & 2500 \\
\hline $\begin{array}{l}\mathrm{O} / \mathrm{u} \text {,P. Maljutin ja pojad" Ramenski } \\
\text { Manufaktuur }\end{array}$ & 265936 & 2005 \\
\hline $\begin{array}{l}\text { Nevski (end. Stieglitzi) puuvillaketrus- } \\
\text { vabrik Peterburis }\end{array}$ & 273132 & - \\
\hline Kreenholmi Manufaktuur & 509280 & 3767 \\
\hline
\end{tabular}

Kolm nimetatud Narva tekstiilivabrikut, millest Kreenholmi vabrik oli suurem kui kaks teist kokku, moodustasid pōhiliselt kogu Narva ja tema piirkonna tööstuse ${ }^{30}$. Hiljem tuli neile lisaks Zinovjevi masinaehitustehas,

29 Ч. М. Иоксимови ч, Мануфактурная промышленность в прошлом и настоящем. M., 1917, стр. 210. Andmeid sísseseadete ja toodangu kohta sai Joksimovitš vabrikute omanike käest.

30 Narva kuulus Peterburi kubermangu koosseisu. Selles kubermangus olid Narva lāhedal Stieglitzi vabrikud, mis hiljem läksid Narva Kalevi Manufaktuuri osaühingu ja Narva Linaketramise Manufaktuuri osaühingu kătte. Kreenholmi saar kuulus Eestimaa kubermangu koosseisu. 
mis tootis aurukatlaid, pumpasid, transmissioone ja malmtooteid. Olejäänud ettevôtted - saeveskid ja toiduainetetööstused olid väikesed ning olulist osa linna majanduslikus elus ei etendanud. Kõige suuremaks nendest oli Zinovjevi saeveski.

Narva tööstuse arengut XIX sajandi lôpul ja XX sajandi algul näitab tööliste arv nimetatud tähtsamates ettevõtetes (tabel 7).

Tabel 7

Tööliste arv Narva ja ümbruskonna tähtsamates ettevōtetes ${ }^{3}$

\begin{tabular}{l|c|c|c|c|c}
\hline \multicolumn{1}{c}{ Nimetus } & 1867. a. & 1879. a. & 1890. a. & 1900. a. & 1914. a. \\
\hline Kreenholmi Manufaktuur & 3130 & 4188 & 4578 & 5402 & 9900 \\
Linaketramise Manufaktuur & 686 & 1078 & 1637 & 2500 & 2000 \\
Kalevi Manufaktuur & 976 & 1074 & 1017 & 1296 & 1200 \\
Masinaehitustehas & - & - & 315 & 497 & 500 \\
Zinovjevi saeveski & - & 75 & 45 & 150 & 300 \\
\cline { 2 - 7 } & 4792 & 6415 & 7592 & 9845 & 13900 \\
\hline
\end{tabular}

Andmed kogu Narva tööstusliku kompleksi elanikkonna arvu kohta puuduvad.

Narva ettevōtteis töötasid eesti ja vene töölised. Näiteks töötas Kreenholmi vabrikus kuulsa 1872 . a. streigi eel 3244 eestlast ja 1400 venelast ${ }^{32}$.

Töölisliikumine Eestis hakkas arenema hiljem kui Venemaa ülejäänud rajoonides. Esimeseks suureks proletariaadi väljaastumiseks Eestis oli streik Kreenholmi Manufaktuuris 1872. a.., mis oli üheks märkimisväärseks sündmuseks Venemaa 70-ndate aastate töölisliikumise ajaloos.

Narva jäi kuni XX sajandi alguseni töölisliikumise peamiseks keskuseks, hiljem aga oli ta Tallinna kōrval kōige tähtsamaks töölisliikumise tugipunktiks Eestis.

Siirdume linnade kolmanda grupi juurde ja alustame selle grupi suurima linna Viln i usega.

Juba enne Vilniuse ühendamist Venemaaga, Poola-Leedu riigi koos. seisus oli ta suureks kaubanduslikuks keskuseks ja linnaks väga arenenud käsitööga. Tal on pikk majandusajalugu.

XIX sajandi alguses oli Vilnius Baltimaade suurim linn, ületades elanikkonna arvu poolest Riia.

Vilniuse elanikkond XIX sajandi esimesel poolel kõikus epideemiate ja sõdade tôttu, kuid üldiselt ei kasvanud ja ulatus umbes 50000 -le.

Vilnius etendas suurt osa kaubandusliku linnana ning väikekaubatootmise ja väiketööstuse keskusena, kuid tema edasiseks kasvuks ei olnud pärisorjusliku majanduse võimutsemise ajal nähtavasti küllaldaselt võimalust.

Reformijärgsel ajajärgul muudab pilti raudtee-ehitus. 1862. a. ehitati läbi Vilniuse Peterburi-Varssavi liin. Samal aastal valmis Riia-Daugav-

sı Tabel on koostatud järgmiste teoste jârgi: Д. А. Т и м ир яз ев, Статистический атлас главнейших отраслей фабрично-заводской промышленности Европейской Россин, вып. І, СПб. 1869, «Указатель» Орлова (1879 г.); «Указатель» Орлова и Будагова (1890 г.); Список фабрик и заводов Европейской Россин, под ред. Варзара, СПб., 1903 , Справочник Кандаурова.

32 A. Vassar, Töölisliikumise algusest Eestis, „Eesti NSV Teaduste Akadeemia Toimetised", 1952, I kd., nr. 1, Ik. 26. 
pilsi raudtee ja Vilniusest oli vōimalik läbi selle sõlmpunkti saada ühendust teiste Venemaa osadega. 1862. a. läks läbi Lentvarise jaama Vilniuse lähedal raudtee kuni Preisi piirini - selle raudtee kaudu kujunes side välismaaga. 70-ndail aastail ehitatud Liepaja-Romnõ magistraal ühendas Vilniuse linna Vasemakalda-Ukrainaga. Lōpuks, strateegiline raudteeliin Vilnius-Rovno, mis ehitati 1880-ndatel aastatel, ühendas Vilniuse Paremakalda-Ukrainaga.

Seega kujunes Vilnius väga tähtsaks raudteesōlmpunktiks ja muutus kuue nn. loodekubermangu, s. o. Leedu ja Valgevene tunnustatud keskuseks. Vilniuses oli suureulatuslik kaubandus, mis haaras nii hulgi- kui jaemüüki.

Siiski jäi kaubakäive Vilniuses ühe kaubandusega tegeleva isiku kohta kaks korda väiksemaks kui Riias või Tallinnas. Tööstuses valitses väikekaubatootmine. Statistika väiketootmise kohta oli tsaariajal väga halb ja siin on arvudest raske rääkida. Kuid 1897. a. loenduse andmeil tegeles Vilniuses tööstusega üldse 20000 inimest. Kui sellest välja jätta suurtööstuse töölised, siis tegeles Vilniuses 16000 inimest väiketööstusega. See tööstus tootis eeskätt valmisriideid ja sukki. 16000 -st Vilniuse väiketööstuse töötajast oli 8000 ōmblus- ja sukatöölist. Peale selle oli Vilniuses arenenud nahatöötlemine, paberist töödeldavate esemete tootmine, toiduainetetööstus. Väiketootmise baasil arenenud manufaktuur kujunes aegamööda ümber vabrikuks. See toimus naha-, toiduainete-, tubaka-, osalt puidutööstuses, paberiesemete tootmises ja vähesel määral metallitööstuses. Vähehaaval kasvades ületas Vilniuse suurtööstustööliste arv 1914, aastal 6000. Köige suuremaks ettevôtteks oli kompvekivabrik, kus töötas 500 inimest.

Kui jälgime Vilniuses tööliste keskmise arvu muutumist ühe suurtööstuse ettevōtte kohta, siis selgub, et ühe vabriku kohta oli XIX sajandil 40 , XX sajandil ligi 70 töölist, s. o. XIX sajandil kaks korda vähem, XX sajandil aga kolm korda vähem kui Riias. See tõi Vilniuse töölisliikumise ajaloosse erinevaid jooni.

Vastavalt Vilniuse majanduslikule arengule toimus ka elanikkonna arvu kasv: 1863. aastal oli linnas 69000 elanikku, 1897. aastal - 155000 ja 1914. aastal -204000 .

D a u g v pils i majanduslik areng reformijärgsel perioodil sarnanes paljus Vilniuse majanduslikule arengule. Kuid mastaabid olid siin tunduvalt väiksemad. Siiski ulatus tema elanikkond esimese maailmasõja eel 100000 inimesele.

T a rtu oli XIX sajandi esimesel poolel sisekaubanduse keskuseks, pärast 1861. a. reformi sai ta raudteeühenduse, kuid jäi kohaliku tähtsusega keskuseks. Seal tekkis ainult üks ülevenemaalise tähtsusega ettevôte - telefonivabrik.

Väga huvitav on S i a u 1 i a i - Põhja-Leedu keskuse - ajalugu. Seal kujunes toiduainete- ja nahatööstuse keskus.

Lōpetame kahe linnaga: Pärnu ja Ventspils. Pärnu jäi pärast 1861. a. reformi umbes samale tasemele nagu ennegi. Tööstuse osas sai Pärnu ühe suurema vabriku - tselluloosivabriku. Kaubanduse osas jäi Pärnu kohaliku tähtsusega keskuseks.

Majanduslikus suhtes oli Ventspils väga kaua, kuni XX sajandi alguseni, sarnane Pärnuga. Kuid 1901. aastal sai ta raudteeühenduse Moskvaga ja selle tagajärjel kujunes suure tähtsusega sadamaks. Ta ületas kaubavahetuse poolest teised sadamad, jõudes ette Liepajast ja võrdudes peaaegu Tallinnaga. Ventspilsi kaudu eksporditi kaupu kogu Venemaalt; 1913. aastal läks $70 \%$ Siberi vōi väljaveost Ventspilsi kaudu. 
On huvitav, et $\mathrm{Kl}$ a i pe $\mathrm{d} a$, mis asetses poliitilises môttes mitte Venemaal, vaid Preisis, toitus majanduslikult tervikuna Leedu ja Venemaa arvel. Mööda Neemeni jõge parvetati metsa, mis töödeldi Klaipedas. Selle linna tööstus areneski peamiselt valgevene ja leedu metsa arvel.

5.

Jälginud Baltimaade mitmesuguste keskuste arengu põhijooni, näeme, et ühed neist arenesid kapitalistlikul ajajärgul kiiremini, teised aga aeglasemalt. Baltimaade keskused arenesid seda kiiremini, mida kiiremini ja tihedamalt nad seostusid ülevenemaalise rahvamajandusega.

Linnade proletariaadi koosseisus olid Lätis peamiselt lätlased, nende kôrval vene proletariaadi märkimisväärsed kaadrid, Eestis - eestlased ja venelased, Leedus - leedulased, juudid, valgevenelased. Ka läksid leedu küladest väljarändajad sageli Läti linnadesse tööle. Baltimaade linnade proletariaat oli klassiteadvuselt ühtne, vaatamata erinevustele rahvuslikus kuuluvuses, klassivõitluses toimusid tema väljaastumised omavahelises sōpruses, osana Venemaa proletariaadi vōitlusest. 1905. aasta näitas seda eriti hästi. See uurimistöö, mida nõukogude ajaloolased praegu teostavad 1905. a, revolutsiooni kohta, näitab, et 1905, a. revolutsioon oli neis vabariikides üldvene revolutsiooni osa.

Baltimaade linnade elanikkonna kasv kapitalismi ajajärgul toimus töökäte juurdevoolu arvel külast. Tänu sellele langes Läti ja Eesti linnades saksa elanikonna erikaal. Nii soodustas Läti ja Eesti linnade majanduslik areng, mis toimus tänu nende lülitumisele kapitalistliku Venemaa rahvamajandusse, nende linnade rahvuslik-kultuurilise ilme muutumist põhirahvuste tugevnemise suunas. Riias oli 1876. aastal sakslasi $45 \%$, lätlasi $24 \%$, aga 1913 . aastal sakslasi $14 \%$ ja lätlasi $41 \%$; Tallinnas oli 1871. aastal sakslasi $32 \%$, eestlasi $49 \%$, aga juba 1897, aastal - sakslasi $16 \%$ ja eestlasi $63 \%$.

Leedus on see protsess vähem ilmekas, seda enam, et tunduv osa töölisi siirdus Leedu külast mitte Leedu linnadesse, vaid kiiremini arenevasse Riiga ja Liepajasse.

Kodanlik-natsionalistliku diktatuuri perioodil, Baltimaade eemaldumisel Venemaast, Eesti ja Läti linnad degradeerusid, toimus rahvamajanduse agrariseerimine ja linnade langus. Teame samuti, mis toimus Vilniusega kodanliku Poola kätes; on küllaldane tuua kaks arvu: 1914. aastal oli Vilniuses 204000 elanikku, 1931. aastal aga 208000, seega tegelikult mingisugust elanikkonna kasvu ei toimunud.

Kui Balti riigid läksid 1940. aastal Nõukogude Liidu koosseisu, algas nende ajaloos uus ajajärk. Selle uue ajajärgu katkestas ajutiselt sōda. Kuid pärast sõja võidukat lõppu hakkasid Baltimaade linnad uuel majanduslikul alusel - sotsialistlikul alusel - ennenägematult kasvama. Ning kui meenutada, mis partei XIX kongressi direktiivides on kirjutatud iseäranis Balti vabariikide kohta, siis on môistetav, kui erakordselt suure ōitsengu osaliseks saavad Baltimaade linnad käesoleval viisaastakul.

NSV Liidu Teaduste Akadeemia Ajaloo Instituut

Saabus toimetusse 24. VI 1953 


\title{
ЗНАЧЕНИЕ ЭКОНОМИЧЕСКИХ СВЯЗЕЙ С РОССИЕЙ ДЛЯ ХОЗЯИСТВЕННОГО РАЗВИТИЯ ГОРОДОВ ПРИБАЛТИКИ В ЭПОХУ КАПИТАЛИЗМА *
}

\author{
в. К. ЯцУНскии, \\ доктор нсторических наук
}

Резнме

Города Прибалтики имеют длительную историю, на протяжении которой постепенно создавалась база для их последующего экономического развития в эпоху капитализма.

В эпоху капитализма прибалтийскне города в экономическом отношении были тесно связаны с народным хозяйством России, и это оказало решающее влияние на их развитие. Большую роль в этом отношенни сыграло строительство железных дорог.

По характеру экономического развития города Прибалтики можно подразделить на три типа.

Первый тип - промышленные города. Из более крупных центров чисто промышленным городом была только Нарва.

Второй тип - это города преимущественно торговые. В них промышленность по сравнению с торговлей была развита слабо, и это была в основном мелкая промышленность. Самым крупным из этих городов был Вильнюс. В составе этой группы городов надо различать две подгруппы - центры внутренней торговли (Вильнюс, Даугавпилс, Тарту, Шауляй и почти все мелкие города) и портовые города (Пярну, Вентспилс, а из мелких городов Кингисепп и Хаапсалу).

Третий тип - это города торгово-промышленные, в которых и промышленность, и торговля были одинаково развиты. В эту группу входили три основных порта Прнбалтики - Рига, Таллин и Лиепая. Сюда же можно отнести также Қаунас и Елгаву, хотя промышленность в них была развита значительно слабее, чем торговля.

Среди торгово-промышленных городов Прнбалтики на первом месте стояла Рига. Ее промышленность и торговля получили значительное развитие еще до 60-х годов XIX века и обслуживали не только Прибалтику. В период капитализма, благодаря росту железных дорог, значительно расширились и укрепились экономические связи Риги с внутренними губерниями России. Это способствовало росту оборотов рнжского порта. В XX веке Рига по экспорту занимала первое место среди портов Россин, а по импорту уступала лишь Петербургу. Промышленность Риги стала все больше и больше работать на всероссий. ский рынок и благодаря этому очень быстро росла. За 1864-1913 годы чнсленность рабочнх, занятых в рижской крупной промышленности, увеличилась в 13 раз. Уже в 1879 году, по подсчетам В. И. Ленина, Рига по числу промышленных рабочих уступала только Петербургу и Москве. По типу и отраслевой структуре промышленность Риги имела много общего с промышленностью Петербурга. Это было результатом сходства географического положения и исторических условий экономи ческого развития обоих городов.

В пернод формирования в России, в том чнсле и в Эстонии, капиталистнческого уклада Таллин в экономическом отношении развивался слабо. Қапиталистическая промышленность Эстонии развивалась в это

- Доклад на второй объединенной научной сессии по истории Прнбалтики (Вильнос, март 1953 г.). О сессни см. «Известия АН ЭССР», 1953, т. II, № 1. 
время вне Таллина - прежде всего в Нарве, а также в таких пунктах, как Синди и Кярдла. Благодаря географнческому положению Таллина и отсутствию связи по водным путям с центральными губерниямми России, район, тяготевший к Таллинскому порту, был невелик н объем внешней торговли Таллина был незначительным, хотя уже тогда ранней весной и поздней осенью Таллин служил вспомогательной гаванью для ввоза товаров в Петербург. В 60-х годах существенного прогресса в экономическом развитии Таллина не наблюдалось. Положение сразу же резко изменилось с постройкой в 1870 году Балтийской железной дорогн. Внешняя торговля Таллнна стала быстро растн. Рос главным образом импорт, обслуживающий, прежде всего, потребности центральных промышленных районов России. В конще XIX и в XX веке Таллин по размерам импорта занимал третье место в России, уступая, кроме Петербурга, еще Одессе и Риге. В 60 -х и 70-x годах промышленное развитие Таллина мало продвинулось вперед. В $80-\mathrm{x}$ годах это развитие немного ускорилось, и продукция таллинских фабрик и заводов начинает, кроме удовлетворения местного спроса, в значительных количествах направляться и на русский рынок. Во время промышленного подъема $90-\mathrm{x}$ годов промышленность Таллина сильно развилась. В XX веке - после кризиса 1900 года и последовавшей за ним депрессии - рост промышленности возобновился. По составу отраслей промыпленности Таллин имел некоторое сходство с Ригой, но удельный вес машиностроения в нем был значительно больше. Таллинская промышленность, как и рижская, работала преимущественно на рынок России.

Нарва развивалась как центр текстильной промышленности. Предпосылкой ее промышленного развития было ее географическое положение и наличие водной энергии. Ее основные предприятия были основаны еще в дореформенную эпоху петербургскими и московскими капиталистами для пронзводства товаров на русский рынок и рано приобрели всероссийское значенне.

Тарту был торговым центром юго-восточной Эстонни; в промышленном отношении он развивался слабо. Но его завод телефонной аппаратуры имел всероссийское значение.

Пярну оставался портом местного значения. Его торговля росла медленно.

Таким образом, города Прибалтики в эпоху капитализма развивались неодинаково. Быстро росли те города, которые обслуживали не только местные нужды самой Прибалтики, но и все народное хозяйство России. Такими городами были, в первую очередь, Рига, Таллин, Лиепая и Нарва.

Формировавшийся в городах Прибалтики пролетариат, несмотря на национальные различия, был единым в своем классовом сознании и выступал сплоченно, как часть революционного класса России.

В период буржуазно-националистической диктатуры, в результате отрыва Прибалтики от России произошла деградация крупных торгово-промышленных центров Прибалтики, упало их экономическое значение.

Вхождение Латвии, Эстонии и Литвы в состав Советского Союза привело к экономическому расцвету городов Прибалтики, но уже на иной, социалистической основе. 